Article

\title{
Response of Fattening Rabbits with Acorns (Quercus pubescens Willd.) Combined in the Diet: First Acquaintances on Growth Performance, Carcass Traits and Perirenal Fatty Acid Profile
}

\author{
Petra Wolf ${ }^{1, *(1)}$ and Maria Grazia Cappai ${ }^{2}$ (1) \\ 1 Institute of Nutrition Physiology and Animal Nutrition, University of Rostock, Justus-von-Liebig-Weg 6b, \\ 18059 Rostock, Germany \\ 2 Department of Veterinary Medicine, Università di Sassari, Via Vienna 2, 07100 Sassari, Italy; \\ mgcappai@uniss.it \\ * Correspondence: petra.wolf@uni-rostock.de; Tel.: +49-381-498-3320
}

Received: 27 June 2020; Accepted: 6 August 2020; Published: 11 August 2020

check for updates

Simple Summary: Consumption of rabbit meat has increased markedly over the last 50 years. This trend appears to be a driving force behind modern farming practices, in particular of rabbit feeding, more and more oriented to fulfil consumers' demand of sustainable, welfare and health-friendly and low-impact animal production. In this context, the deployment of alternative feeding sources with particular biological properties in the production of feed for meat-producing animals is worthy of being investigated. This trial explored the effect of the combination of acorns as a whole ingredient in the diet of fattening rabbits with the aim to acquire pioneering information on the production and health parameters, in view of the potential effects of the diet on growth, carcass wear and fatty acid composition of perirenal fat.

\begin{abstract}
The request for functional and healthy meat presents a challenge to modern animal nutritionists and rabbit meat consumption appears to increase alongside the aging population. Novel functional feeds for food-producing animals gather the interest of the scientific community and acorns appear frequently accounted among non-competitive-with-human feeding sources, above all in slow food production systems. This investigation aimed to assess the response to acorns combined in the diet of 40 fattening rabbits, in respect of growth performance, carcass characteristics and fatty acids composition in perirenal fat. A same commercial fattening diet combined or not with shredded acorns (control, $\mathrm{CON}=0 \mathrm{vs}$. acorn combined diet, $\mathrm{ACD}=200 \mathrm{~g} / \mathrm{kg}$ feed as fed weight, respectively) was administered for six weeks to two groups of Separator rabbits, consisting of 20 animals each. No differences in feed conversion, carcass weight at slaughter and carcass yields ( $24 \mathrm{~h}$ ) were found between groups at the end of the experimental feeding. Perirenal fat profile of rabbits from the ACD group pointed to significant differences in $\Sigma$ PUFA content (25.1 vs. 31.6, as a percentage of total lipids, respectively, $p<0.001$ ) and in the $\Sigma n-6 / n-3$ ratio (5.95 vs. 2.41). In conclusion, acorns can be used as an energy source in mixed feeds for rabbits, especially in slow production systems.
\end{abstract}

Keywords: fatty acids; flavour; functional food; PUFA; rabbit

\section{Introduction}

Consumption of rabbit meat increased markedly over the last 50 years and this trend appears to be shaping modern farming practices. In particular, feeding practices are oriented to fulfil consumers' demand of functional and healthy meat, and for ethical and sustainable food production [1]. Recently, 
the potential of rabbit meat as a functional food was reviewed [2] in light of the most up-to-date breeding and feeding strategies. In this scenario, the increasing aging population and the high prevalence of metabolic disorders represent public health issues in developed countries, which seem to positively correlate and drive consumer's preference for rabbit meat. Such a demand poses a question to animal nutritionists about the chance offered by functional feedstuffs to be used in rabbit feeding practices of slow production systems. In this regard, investigations on biologically active compounds, purified or contained in alternative ingredients used in dietary formulations, continuously gather the interest of the scientific community in the field of animal nutrition, as well as of feed and food industries. In some Mediterranean countries, different extensive animal productions take advantage of the seasonal availability of natural feeding stuffs, which turned to be fundamental ingredients for traditional meat productions as a non-competitive-with-human feeding source. The use of ripe acorns for grazing and browsing livestock in oak forests appears a valuable seasonal feeding strategy thanks to energy concentration, polyphenolic profile, Vitamin E and high Zn contents [3-12]. Acorns can be consumed directly by free ranging animals or else be included in mashed diets, should free grazing not be practicable [7]. In view of this aspect, acorns can also be collected and offered to provide sustainable dietary energy sources to semi-extensively raised pigs during the fattening period, especially for the production of cured ham, thanks to high starch and a peculiar acidic profile $[13,14]$.

Nutrient composition of acorns identifies these fruits as energy-rich feedstuffs (starch 512-571 g and 42-63 g crude fat content in $\mathrm{kg}$ dry matter) [14]. Therefore, acorns can serve as concentrate feeds in extensive breeding systems [14] chiefly in feed mixtures [15,16] due to biologically active compounds (polyphenols profile) and to the peculiar pattern of fatty acids [14]. A number of studies on the use of acorns was carried out in pigs and, to a lesser extent, in ruminants and poultry. Although the study by Zamora-Lozano and co-workers [17] provided very promising results, only a few studies in rabbits can be found in the scientific literature. An advantage of the use of acorns in animal feeding resides in the production of special niche products, like in the case of several well-known pork productions (Iberic pork and its Iberic ham or Nebrodi pork production, for instance [18,19]).

Acorns are rich in polyphenols and their biological role as natural anti-oxidants may also be exploited to confer stability to rabbit meat. However, acorns are known to be rich in hydrolysable tannins, varying in spectrum and concentration according to the botanical origin and ripening of the fruit. At his regard, it is well known that some animal species are capable of tolerating acorn tannins in the diet [20] whilst others are not. Such adaptation to cope with tannin-rich feeding stuffs is, in some cases, mitigated by salivary secretion and composition. In particular, parotid gland secretions are called forth when potentially toxic substances of diverse origin are ingested [21]. The success to buffer the protein precipitating activity (PPA) of tannic acid (TA) is due to the secretion of tannin binding proteins, in particular histatins and proline-rich protein (PRP) [22]. Against this background, basic data on the safe use of acorns as functional feeds in rabbits appears scanty to date. In view of this state of the art, the question on the use of acorns as functional ingredients in the diet of fattening rabbits needs to be elucidated. For this reason, a feeding trial was carried out with the aim to explore the effects of acorn inclusion in the diet of fattening rabbits and to correlate this ingredient provision with production performance in vivo as well as with carcass characteristics. In addition, first acquaintances would be acquired about the meat flavour and fatty acid profile of perirenal fat as a body source to evaluate the change of animal fatty acid composition in view of acorn intake.

\section{Materials and Methods}

\subsection{Animals and Diets}

Animal handling complied with the recommendations of European Union Directive 2010/63/EU [23] concerning animal care. All procedures reported in this trial belong to conventional clinical and breeding practices; in particular, feeding, body weight record and slaughter were carried out in respect of current European legislation on animal protection. The study was approved by 
the State Office for Agriculture, Food Safety and Fisheries of Mecklenburg-Western Pomerania, no. 7221.3-3.2-002/17.

The experiment was carried out at the University of Rostock, enrolling 40 weaned, 36 days-old rabbits (20 female/20 male rabbits, breed: Separator; body weight at start: $703 \pm 22.5 \mathrm{~g}$ ). Animals came from one same farm and were distributed to two groups according to a matched-pairs approach, based on body weight and litter origin (no. 8 litters from relative does), in respect of a sex ratio 1:1 in both groups. Each group consisted of 20 rabbits. All animals were individually housed in metabolic cages $\left(90 \times 90 \mathrm{~cm}, 8100 \mathrm{~cm}^{2}\right)$ without bedding material. During the following 40 days, one groups was fed a commercial fattening feed, whereas the other group was fed the same commercial fattening feed combined with $200 \mathrm{~g}$ of shredded acorns (collected in Sardinia and belonging to the Q. pubescens Willd. oaks) per $\mathrm{kg}$ diet, on an as fed basis (see Table 1), later included in the pellet. Feed was offered ad libitum (calculated according to the maximum daily DM intake in $g$ as a percentage of body weight and adjusted according to daily consumption) and all the animals had free access to fresh water throughout the entire trial. Experimental diets were conceived according to the ingredient combination technique [20], which aims to provide information on the effect of a whole ingredient at a certain amount in the diet. In this experiment, acorns were used to substitute sunflower extruded meal and inclusion amount tested was established to explore whether a safe tannic acid intake can be tolerated in relation to rabbit health and response. For these purposes, acorns were introduced in the pelleted feed ( $20 \%$ in the experimental diet, as fed). Moreover, acorns were previously characterized for the full polyphenolic spectrum in previous trials [24]. Feed intake of rabbits in both groups was determined daily, whereas body weight was recorded once a week for average daily weight gain calculation. Feed leftover was removed from the feeder and weighed daily. On the basis of weight and chemical composition of feed and leftovers, determinations were used to calculate daily DM and tannin acid equivalent (TAE) intakes per $\mathrm{kg}$ BW.

Table 1. Analysed nutrient composition of pure acorns.

\begin{tabular}{ccc}
\hline Nutrient & Unit & Content \\
\hline Dry matter & $\mathrm{g} / \mathrm{kg}$ as fed & 612 \\
\hline Crude ash & $\mathrm{g} / \mathrm{kg} \mathrm{DM}$ & 21 \\
\hline Crude protein & $\mathrm{g} / \mathrm{kg} \mathrm{DM}$ & 57 \\
\hline Crude fat ${ }^{*}$ & $\mathrm{~g} / \mathrm{kg} \mathrm{DM}$ & 83 \\
\hline Crude fibre & $\mathrm{g} / \mathrm{kg} \mathrm{DM}$ & 1445 \\
\hline NfE & $\mathrm{g} / \mathrm{kg} \mathrm{DM}$ & 694 \\
\hline Starch & $\mathrm{g} / \mathrm{kg} \mathrm{DM}$ & 453 \\
\hline Calcium & $\mathrm{g} / \mathrm{kg} \mathrm{DM}$ & 1.64 \\
\hline Phosphorus & $\mathrm{g} / \mathrm{kg} \mathrm{DM}$ & 0.97 \\
\hline Magnesium & $\mathrm{g} / \mathrm{kg} \mathrm{DM}$ & 0.62 \\
\hline Sodium & $\mathrm{g} / \mathrm{kg} \mathrm{DM}$ & 0.25 \\
\hline Copper & $\mathrm{mg} / \mathrm{kg} \mathrm{DM}$ & 5014 \\
\hline Zinc & $\mathrm{mg} / \mathrm{kg} \mathrm{DM}$ & 9067 \\
\hline Selenium & $\mathrm{mg} / \mathrm{kg} \mathrm{DM}$ & $<0.01$ \\
\hline${ }^{*}$ Fatty acid pattern $(\%): 60 \mathrm{oleic} / 24$ linoleic/14 palmitic/1.5 linolenic.
\end{tabular}

\subsection{Chemical Analyses}

The chemical composition of the diet and samples was carried out according to proximate analysis, and modified methods [25], in duplicates of each sample. Starch content of the diets was determined according to the official polarimetric method (1999/79/CE) [26]. From whole acorn samples, different 
aliquots were used to carry out further chemical analyses, like amino acids (AA, in particular lysine, cysteine, methionine and proline) were determined by ion-exchange chromatography (amino acids analyser: Eppendorf-Biotronic, model LC 3000, Eppendorf.Biotronic, Hamburg, Germany). Macro and micro elements were determined by atomic absorption spectrometry except for P. The total polyphenols and the TAE were determined by the Folin-Ciocalteau [27] modified method [28]. Analysed nutrient contents of the two experimental diets are reported in Table 2. A sample of crude fat was methylated to obtain the fatty acid methyl esters (FAME): thereafter, FAME were analysed using a Hewlett-Packard HP-5890 gas chromatograph (Agilent Technologies Inc., Lexington, MA, USA) and identified through standard samples. The content of polyunsaturated fatty acid (PUFA) in DM was determined and expressed on total crude fat. The fatty acid profile of the two experimental diets is reported in Table 2 .

Table 2. Analysed nutrient composition and fatty acid profile of the two experimental diets.

\begin{tabular}{|c|c|c|}
\hline Ingredients (g/kg Diet, as Fed) & Control Diet & Acorn Combined Diet \\
\hline Alfalfa green meal & 300 & 300 \\
\hline Wheat bran & 270 & 270 \\
\hline Sunflower extruded meal & 200 & - \\
\hline Hulled acorn shred & - & 200 \\
\hline Oat peel bran & 100 & 100 \\
\hline Barley & 80 & 80 \\
\hline Beet pulp molasses & 20 & 20 \\
\hline Calcium carbonate & 19 & 19 \\
\hline Sodium chloride & 6 & 6 \\
\hline Premix & 5 & 5 \\
\hline Crude protein (g/kg DM) & 160 & 146 \\
\hline Lysin (g/kg DM) & 10.1 & 8.35 \\
\hline Met + Cys (g/kg DM) & 9.34 & 7.19 \\
\hline Proline (g/kg DM) & 13.0 & 10.4 \\
\hline Crude fibre (\%) & 170 & 162 \\
\hline Starch (g/kg DM) & 236 & 241 \\
\hline \multicolumn{3}{|c|}{ Fatty acid composition (mg/kg of total fatty acids) } \\
\hline $14: 0$ & 0.69 & 0.68 \\
\hline $14: 1$ & 0.17 & 0.14 \\
\hline $16: 0$ & 28.1 & 17.7 \\
\hline 16:1n-7 & 0.49 & 0.47 \\
\hline 18:0 & 3.59 & 4.12 \\
\hline $18: 1 n-9$ & 28.1 & 22.5 \\
\hline $18: 2 n-6$ & 32.4 & 35.6 \\
\hline $20: 0$ & 0.35 & 0.64 \\
\hline $18: 3 n-3$ & 5.82 & 15.4 \\
\hline $20: 1 n-9$ & 0.41 & 0.42 \\
\hline $20: 2$ & 0.19 & 0.16 \\
\hline$\Sigma$ SFA & 32.77 & 23.1 \\
\hline$\Sigma$ MUFA & 29.2 & 23.5 \\
\hline$\Sigma$ PUFA & 38.4 & 51.2 \\
\hline$\Sigma \mathrm{n}-6 / \Sigma \mathrm{n}-3$ & 5.57 & 2.31 \\
\hline
\end{tabular}




\subsection{Response of Parotid Glands to Dietary Acorn Tannins, Quantitative Evaluation of the Carcass and Organoleptic Traits of Meat}

At the end of the experiment (day 76) all animals were slaughtered in a conventional slaughterhouse, where the carcasses were tracked in the slaughtering chain and were subjected to both carcass evaluation and organoleptic testing (roast test).

The assessment of morphology and composition of the parotid gland (PG) was carried out as a way to estimate rabbit response to dietary tannins contained in the acorn combined diet, in the attempt to counteract the protein precipitating activity of TAE. The evaluation of the PG followed the method described by Cappai and co-workers $[9,20]$ in pigs. Briefly, both PGs were surgically removed from the carcass of each rabbit, and excised in toto. After removing the separable fat, lymph nodes and associated vessels, each PG was immediately weighed on a digital scale. Length and width $(\mathrm{mm})$ were measured by means of an electronic digital caliper (799A-6"/150 mm, L.S. Starrett Company, Athol, MA, USA).

The glands in toto were oven dried $\left(103^{\circ} \mathrm{C}\right)$ and then ground; samples were analysed in duplicate for dry matter, crude protein and amino acids as described earlier. Proline content on the dry matter of the respective parotid gland was calculated as a response parameter for proline rich protein synthesis. Relative fresh weight of each parotid gland was calculated according to the body weight of the respective animal before slaughter and expressed as percentage. A proline/CP ratio was also calculated based on proline content $(\mathrm{g} / \mathrm{kg} \mathrm{DM})$ and $\mathrm{CP}$ content $(\mathrm{g} / \mathrm{kg} \mathrm{DM})$ of the same parotid gland.

For the organoleptic test, an aliquot of $5 \times 5 \times 1 \mathrm{~cm}$ was extracted out of the musculus quadriceps femoris. In brief, on each warm carcass, a surgical window at the level of the proximal third of the lateral side of the left leg was open by means of a scalpel with single use blade and $1 \mathrm{~cm}$ thick muscle sample removed. Each muscle sample was stored in individual falcon tubes $(50 \mathrm{~mL})$ to be transported to the laboratory in a freezing bag. For the taste panel only meat flavour was assessed at this stage. Each muscle sample was roasted in a pan with corn oil at constant temperature and time, following internal standard method of the laboratory. The samples were tested by two trained persons (always the same ones) who judged whether the meat was more or less aromatic though a semi-quantitative evaluation score (1-5 point scale, where 1 is less aromatic and 5 is for very aromatic). This worked as a preliminary assessment due to the presence of natural tannic acid (expressed as TAE in acorns, known to be a flavouring agent.

The determinations of lipid and fatty acid profiles were carried out on perirenal fat. This evaluation was driven by the establishment that in rabbits' perirenal fat depot strongly correlates with all carcass fat weight [29]. Kidneys were excised from each warm carcass and separable fat removed and stored in an individual fashion to be transported to the laboratory. Samples were processed for fatty acids following the methods reported above.

\subsection{Calculations and Statistics}

For the evaluation of the normal distribution, the $t$-test for paired observations was used. Data were analysed with a general linear model as reported below:

$$
\mathrm{Y}_{i, j}=\mu+\mathrm{D}_{i, j}+\mathrm{Z}_{m, n}+\mathrm{D} \times \mathrm{Z}+\mathrm{e}_{i, j, m, n}
$$

where $\mathrm{Y}$ is the effect on PG response, sensory score and fatty acids profile, $\mu$ is the overall mean, $\mathrm{D}$ is the fixed effect of the diet (two levels: 0 vs. $20 \%$ of acorns in the diet), $Z$ is the fixed effect of gender, $\mathrm{D} \times \mathrm{Z}$ is the interaction between the diet and gender and $e$ is the random error. Data were analysed by means of Minitab_18 ( ${ }^{\odot} 2020$ Minitab, LLC, State College, PA, USA). All statements of statistical significance are based upon $p<0.05$. 


\section{Results}

No differences in the daily amounts of feed consumed were observed between groups (see Table 3). No differences between genders were observed.

Table 3. Production performance in rabbits (control vs. acorn combined diets) diet group ( $\mathrm{n}=20$ rabbits/group; values expressed as means \pm standard error).

\begin{tabular}{ccc}
\hline Parameter & Control Diet & Acorn Combined Diet \\
\hline Daily feed intake $(\mathrm{g} / \mathrm{d}$; days 37-76) & $114 \pm 26.4$ & $122 \pm 22.1$ \\
\hline Feed conversion ratio $(\mathrm{g} / \mathrm{g})$ & $3.19 \pm 0.56$ & $3.48 \pm 0.31$ \\
\hline Final body weight $(\mathrm{g} \mathrm{BM}$; day 76$)$ & $2130 \pm 125$ & $2157 \pm 134$ \\
\hline Salivary gland $(\%$ of BM) & $0.252 \pm 0.035^{\mathrm{a}}$ & $0.325 \pm 0.028^{\mathrm{b}}$ \\
\hline Proline content $(\mathrm{g} / \mathrm{kg} \mathrm{DM})$ & $88 \pm 30$ & $93 \pm 27$ \\
\hline Liver weight $(\%$ of BM) & $5.03 \pm 0.78$ & $5.15 \pm 0.64$ \\
\hline Perirenal fat $(\%$ of BM) & $0.99 \pm 0.17$ & $1402 \pm 84$ \\
\hline Carcass weight $(\mathrm{g})$ & $1394 \pm 89$ & $64.9 \pm 2.89$ \\
\hline Cold carcass yield $(\%)$ & $65.4 \pm 2.57$ &
\end{tabular}

The TAE of acorns were $51.6 \mathrm{~g} / \mathrm{kg}$ DM providing an amount of $10.2 \mathrm{~g}$ TAE $/ \mathrm{kg}$ DM in the combined diet. Salivary glands (PG) of the rabbits fed with the acorn combined diet displayed significant differences in response to the tannin-rich acorn-based diet, as to increased proline content as well as to the weight and size of the gland (Table 3).

Table 4 reports the fatty acid profile of perirenal fat of rabbits from both groups. Significantly, PUFA content is higher in the perirenal fat of rabbits fed with the acorn combined diet. In addition, $\Sigma$ n-6/ $\Sigma$ n-3 ratio in acorn fed rabbits displayed to be significantly different (Table 4).

The flavour of rabbit meat revealed differences between the two groups fed with the different diets. In fact, in the $94.7 \%$ of tests the meat from rabbits fed acorns was assessed to be more aromatic than that of rabbits from the control group (Figure 1). This finding was not correlated with the fatness of the carcass and, in turn, with the energy content of the ration.

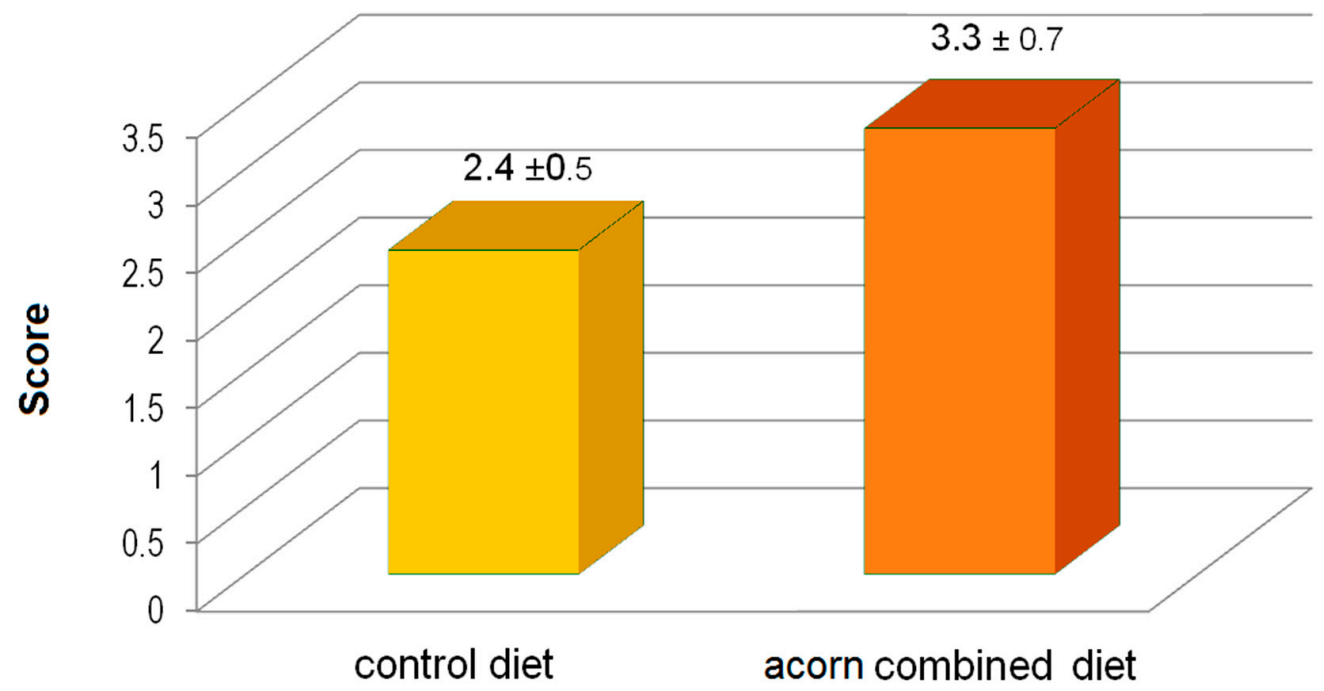

Figure 1. Histograms of scores (1-5 point scale) of a panel test of roasted meat from musculus quadriceps femoris assessed for aromatic properties by independent trained experts. Values are expressed as mean values \pm standard error. 
Table 4. Total lipid content and fatty acids composition of perirenal fat of rabbits fed with the two experimental diets (total lipids: $\mathrm{g} / \mathrm{kg}$; fatty acid composition: $\mathrm{mg} / \mathrm{kg}$ fatty acids; mean $\pm \mathrm{SD}$ ).

\begin{tabular}{|c|c|c|}
\hline & Control Diet & Acorn Combined Diet \\
\hline Total lipids & $73.6 \pm 1.57$ & $74.1 \pm 1.83$ \\
\hline $14: 00$ & $2.41 \pm 0.29$ & $2.27 \pm 0.45$ \\
\hline $14: 01$ & $0.14 \pm 0.01$ & $0.17 \pm 0.08$ \\
\hline $16: 00$ & $31.8 \pm 3.37$ & $28.6 \pm 2.49$ \\
\hline $16: 1 n-7$ & $3.59 \pm 1.74$ & $2.71 \pm 0.89$ \\
\hline 18:00 & $5.84 \pm 0.19$ & $6.21 \pm 0.87$ \\
\hline $18: 1 n-9$ & $30.5 \pm 3.07$ & $27.3 \pm 2.21$ \\
\hline $18: 2 n-6$ & $21.2 \pm 0.64$ & $22.1 \pm 0.99$ \\
\hline 20:00 & $0.14 \pm 0.08$ & $0.15 \pm 0.05$ \\
\hline $18: 3 n-3$ & $3.30 \pm 2.19$ & $8.89 \pm 4.89$ \\
\hline $20: 1 n-9$ & $0.38 \pm 0.03$ & $0.37 \pm 0.01$ \\
\hline 20:02 & $0.15 \pm 0.00$ & $0.16 \pm 0.00$ \\
\hline $20: 3 n-3$ & $0.11 \pm 0.00$ & $0.12 \pm 0.01$ \\
\hline $20: 4 n-6$ & $0.10 \pm 0.01$ & $0.14 \pm 0.06$ \\
\hline $22: 1 n-9$ & $0.06 \pm 0.00$ & $0.07 \pm 0.01$ \\
\hline $20: 5 n-3$ & $0.05 \pm 0.00$ & $0.06 \pm 0.01$ \\
\hline 24:00:00 & $0.06 \pm 0.01$ & $0.05 \pm 0.00$ \\
\hline $24: 1 n-9$ & $0.07 \pm 0.01$ & $0.04 \pm 0.00$ \\
\hline $22: 5 n-3$ & $0.06 \pm 0.01$ & $0.05 \pm 0.00$ \\
\hline $22: 6 n-3$ & $0.06 \pm 0.01$ & $0.09 \pm 0.02$ \\
\hline$\Sigma$ SFA & 40.3 & 37.3 \\
\hline$\Sigma$ MUFA & 34.7 & 30.7 \\
\hline$\Sigma$ PUFA & $25.1^{\mathrm{a}}$ & $31.6^{b}$ \\
\hline$\sum n-6 / \sum n-3$ & $5.95^{\mathrm{a}}$ & $2.41^{\mathrm{b}}$ \\
\hline
\end{tabular}

\section{Discussion}

This feeding trial was carried out to shed a new light on the potential use of acorns in the diet of fattening rabbits. The investigation was planned to explore in vivo and post mortem aspects, on both production and physiological sides. In fact, the tested amount of acorn inclusion ( $200 \mathrm{~g} / \mathrm{kg}$, as fed) offered on a daily basis to rabbits during the fattening period established the first information on the daily intake of the acorn-based diet, in comparison with the control diet. Results of calculations on the daily weights of feed offered minus left-overs did not point to differences in the average feed intake between groups (data not shown). Live body weight collected throughout the trial until slaughter of rabbits pointed to similar daily gains and carcass weight. Interestingly, despite production performance (feed conversion ratio, final body weight) in vivo, we did not highlight differences between groups, significant post mortem differences were observed if rabbits were fed with the acorn-based diet. The hypertrophy of the parotid gland point to the tolerance of the tannin-rich diet by rabbits. Rabbits of the acorn combined diet group showed a significantly higher weight of the gland as well as proline content, at tested amounts. The presence of polyphenols with protein precipitating activity expressed as TAE contributes to forming complexes in the gastrointestinal content between dietary and endogenous proteins from digestive secretion and microbial synthesis which are rich in non-essential amino 
acids (e.g., proline). In agreement with what was observed in parotid glands of pigs fed with acorn combined diets [9,20], and salivary glands of other domestic and wild animal species [22], as well as in primates $[30,31]$, the response to TAE can take advantage of salivary production of proline-rich proteins (PRPs), representing a first mechanism of defence against the protein precipitating activity of dietary tannins, like in this case. This mechanism of defence against dietary tannins could be observed in other animal species adapted to tannin-rich diets with the aim to contrast the protein precipitating activity (PPA). This finding is suggestive of the fact that the adaptation to tannin-rich diets in the rabbit should be efficacious, given the modulation of the secreting activity of the PG from augmented synthesis of proline-rich proteins (PRPs) in the saliva and other potential secretions across the gastrointestinal tract. Such a response involving salivary composition is known to be genetically encoded. In view of being capable of modulating the salivary secretion in response to the PPA of dietary tannins, rabbits may appear tolerant to tannin-rich diets. The presence of tannins and the natural AA pattern of acorns may noticeably reduce the availability of essential AA, with particular regard to sulphur amino acids (SAA). However, no significant depression of daily feed intake was observed in rabbits fed the acorn combined diet in comparison with rabbits fed the control diet in this feeding trial. On the other hand, the favourable pattern of fatty acids of acorns, especially oleic acid, may cover a significant role in the stability of rabbit meat, though not explored in this investigation. To such an extent, the desired effect from acorn consumption observed in pigs appears to also be obtained in rabbits enrolled in this trial, in terms of safe use and potential effect on fatty acid profile of perirenal fat.

In both groups, similar carcass weights were observed, which are also common in animals of approximately the same size [32-34]. By mixing acorns in the diet, the energy content of feed decreased $[35,36]$. The protein content in the compound feed decreased, with the amino acids lysine, methionine, cystine and proline, in particular, being lower in the experimental group receiving the acorn combined diet (see Table 2). This can be attributed to the lower protein content of acorns, which, according to Galvan and co-workers [37], varies in magnitude between 29 and $59 \mathrm{~g} / \mathrm{kg}$. The protein content of $57 \mathrm{~g} / \mathrm{kg}$ analysed in this study corresponds to the upper value of the range from the literature, but also coincides with values from other studies, of 59 [38] and $56 \mathrm{~g} / \mathrm{kg}$ [39]. Cappai and co-workers [14] reported an average value of $37.1 \mathrm{~g} / \mathrm{kg}$. This finding may also depend on the botanic origin of acorns which display varying nutrient contents according to genetic type of oak acorns, also involving TAE content [16]. In all cases, acorn feeding at tested amounts during the fattening period of rabbits points to the safe and sustainable use of acorns as feed ingredients, highlighting the potential of employment as alternative feed in slow production systems. It is also to point out that no economic evaluation has been carried out on the use of acorns to feed fattening rabbits at present, because this practice needs to be explored further. However, results obtained from this investigation appear encouraging and pave the way to future investigations oriented to characterize meat quality traits. In this context, trials are currently ongoing with the final aim to protect the origin of a future local product branded "Mecklenburger Oak Rabbit".

Worth noting, results on the acidic profile of perirenal fat and meat sensory properties highlight significant differences between groups. In particular, the effect on the fatty acid profile from acorn intake is well-described in pigs $[11,35,36,40]$. No descriptions about the fatty acid profile in rabbit fat from acorn consumption are available in the literature to the best of our knowledge. The sensory properties of meat point to different flavours if rabbits are fed with acorns, likely also due to natural TAE in acorns. These results, although preliminary, pave the way to further investigations aimed to explore the effect of acorns in the diet of rabbits for meat quality trait assessment. Additionally, acorns are also valuable sources of tocopherol, involved in several biological activities within the animal body and, in particular, capable to confer a certain stability against the oxidation of meat [11,12]. Like that observed in other herbivores and, in particular, in hindgut fermenters [41,42] Vitamin E status is strictly related to dietary intakes. Deficiency of dietary tocopherols are described in the literature to cause health disorders in rabbits [43]. The provision of tocopherols through acorn feeding may contribute to improving rabbit meat stability, as well as support overall health by helping systemic antioxidant 
status. However, this aspect was not studied in this trial, but represents the focus of future studies in this direction, with the objective to better characterize the effects on production performance of acorn feeding in rabbits.

\section{Conclusions}

This preliminary study shows that acorns can be safely used in fattening rabbits at tested amounts. Rabbits were able to respond successfully to the presence of hydrolysable tannins (TAE) with protein precipitating activity in the diet, naturally contained in acorns, by increasing parotid glands, likely mirroring the augmented secretion of PRPs. Perirenal fat depot was not affected by the diet but fatty acid profile displayed to change: this aspect can allow to consider the potential effects of acorn feeding on the fatty acid profile of meat for future studies. The encouraging results focusing on acorns combined in the diet of fattening rabbits pave the way for further investigations to characterize the meat quality and profile of acorn-fed rabbits as an alternative feeding practice and sustainable management of local rabbit production systems.

Author Contributions: Conceptualization, methodology, software analysis, validation, investigation, data curation, writing — original draft preparation, writing — review and editing: P.W. and M.G.C.; supervision, funding acquisition: P.W. All authors have read and agreed to the published version of the manuscript.

Funding: This research was carried out with internal funding.

Acknowledgments: Authors are thankful to the whole staff of the Institute of Nutrition Physiology and Animal Nutrition, University of Rostock, Germany.

Conflicts of Interest: The authors declare no conflict of interest.

\section{References}

1. Musco, N.; Lombardi, P.; Addeo, N.F.; Secci, G.; Parisi, G.; Pero, M.E.; Piccolo, G.; Nizza, A.; Bovera, F. Mirrors Can Affect Growth Rate, Blood Profile, Carcass and Meat Traits and Caecal Microbial Activity of Rabbits Reared in a "Small Group" Free-Range System. Animals 2019, 9, 639. [CrossRef] [PubMed]

2. Dalle Zotte, A.; Szendrő, Z. The role rabbit meat as functional food. Meat Sci. 2011, 88, 319-331. [CrossRef] [PubMed]

3. Joffre, R.; Rambal, S.; Ratte, J.P. The dehesa system in southern Spain and Portugal as a natural ecosystem mimic. Agroforest. Syst. 1999, 45, 57-79. [CrossRef]

4. Decandia, M.; Sitzia, M.; Cabiddu, A.; Kababya, D.; Molle, G. The use of polyethylene glycol to reduce the anti-nutritional effects in goats fed woody species. Small Rumin. Res. 2000, 38, 157-164. [CrossRef]

5. Gilboa, N.; Perevolotsky, A.; Landau, S.; Nitsan, Z.; Silanikove, N. Increasing productivity in goats grazing Mediterranean woodland and scrubland by supplementation of polyethylene glycol. Small Rumin. Res. 2000, 38, 183-190. [CrossRef]

6. Henkin, Z.; Gutman, M.; Aharon, H.; Perevolotsky, A.; Ungar, E.D.; Seligman, N.G. Suitability of Mediterranean oak woodland for beef herd husbandry. Agric. Ecosyst. Environ. 2005, 109, 155-161. [CrossRef]

7. Pinna, W.; Nieddu, G.; Moniello, G.; Cappai, M.G. Vegetable and animal food sorts found in the gastric content of Sardinian wild boars (Sus scrofa meridionalis). J. Anim. Physiol. Anim. Nutr. 2007, 91, 252-255. [CrossRef]

8. Papanastasis, V.P.; Yiakoulaki, M.D.; Decandia, M.; Dini-Papanastasi, O. Integrating woody species into livestock feeding in the Mediterranean areas of Europe. Anim. Feed Sci. Technol. 2008, 140, 1-17. [CrossRef]

9. Cappai, M.G.; Wolf, P.; Liesner, V.G.; Kastner, A.; Nieddu, G.; Pinna, W.; Kamphues, J. Effect of whole acorns (Quercus pubescens) shred based diet on parotid gland in growing pigs in relation to tannins. Livest. Sci. 2010, 134, 183-186. [CrossRef]

10. Cappai, M.G.; Wolf, P.; Pinna, W.; Kamphues, J. Pigs use endogenous proline to cope with acorn (Quercus pubescens Willd.) combined diet high in hydrolysable tannins. Livest. Sci. 2013, 155, 316-322. [CrossRef] 
11. Rey, A.I.; Daza, A.; Lopez-Carrasco, C.; Lòpez-Bote, C.J. Feeding Iberian pigs with acorns and grass in either free-range of confinement affects the carcass characteristics ad fatty acids and tocopherols accumulation in Longissimus dorsi muscle and backfat. Meat Sci. 2005, 73, 66-74. [CrossRef] [PubMed]

12. Dasa, A.; Mateos, A.; Rey, A.I.; Ovejero, I.; Lòpez-Bote, C.J. Effect of duration of feeding under free-range condition on production results and carcass and fat quality in Iberian pigs. Meat Sci. 2007, 6, 411-461.

13. Tejerina, D.; García-Torres, S.; Cabeza de Vaca, M.; Vázquez, F.M.; Cava, R. Acorns (Quercus rotundifolia Lam.) and grass as natural sources of antioxidants and fatty acids in the "montanera" feeding of Iberian pig: Intraand inter-annual variations. Food Chem. 2011, 124, 997-1004. [CrossRef]

14. Cappai, M.G.; Wolf, P.; Rust, P.; Pinna, W.; Kamphues, J. Digestibility coefficient of crude nutrients in raw hulled acorns (Quercus pubescens Willd.) fed to growing pigs. Anim. Feed Sci. Technol. 2014, 197, 148-154. [CrossRef]

15. Rodriguez-Estevez, V.; Garcia Martinez, C.; Perea Munoz, J.M.; Gomez Castro, A.G. Measures and nutritional characteristics of Quercus acorns from the dehesa. Arch. Zootec. 2008, 57, 1-12.

16. Cappai, M.G.; Alesso, G.A.; Nieddu, G.; Sanna, M.; Pinna, W. Electron microscopy and composition of raw acorn starch in relation to in vivo acorn starch digestibility. Food Funct. 2013, 4, 917-922. [CrossRef]

17. Zamora-Lozano, M.; Sanchez Rodriguez, M.; Gellego Barrera, J.; Mata Moreno, C.; Peinado, L.E. Intake of acorn by rabbits kept under continuous grazing. Arch. Zootec. 1985, 34, 257-265.

18. Chiofalo, B.; Liotta, L.; Zumbo, A.; Chiofalo, L. Seasonal variation of free fatty acids in plasma of Nero Siciliano pigs living in extensive conditions. Vet. Res. Commun. 2013, 27, 253-255. [CrossRef]

19. Lopez-Bote, C.; Fructuoso, G.; Mateos, G.G. El cerdo iberico. Sistemas de procion porcina y calidad de la carne. Cerdo Iber. FEDNA 2000, 16, 77-111.

20. Cappai, M.G.; Wolf, P.; Pinna, W.; Kamphues, J. The bilateral parotidomegaly (hypertrophy) induced by acorn consumption in pigs is dependent on individual's age but not on intake duration. Livest. Sci 2014, 167, 263-268. [CrossRef]

21. Aboling, S.; Droetleff, A.; Cappai, M.G.; Kamphues, J. Contamination with ergot bodies (Claviceps purpurea sensu lato) of two horse pastures in Northern Germany. Mycotoxin Res. 2016, 32, 207-219. [CrossRef] [PubMed]

22. Mehansho, H.; Butler, L.; Carlson, D.M. Dietary tannins and salivary proline rich proteins: Interactions, Induction, and defense mechanism. Annu. Rev. Nutr. 1987, 7, 423-440. [CrossRef] [PubMed]

23. Directive 2010/63/EU of the European Parliament of and of the Council of 22 September 2010 on the Protection of Animals Used for Scientific Purposes. 2010. Available online: https://eur-lex.europa.eu/LexUriServ/ LexUriServ.do?uri=OJ:L:2010:276:0033:0079:en:PDF (accessed on 26 June 2020).

24. Aldritt, I.; Whitham-Agut, B.; Sipin, M.; Studholme, J.; Trentacoste, A.; Tripp, J.A.; Cappai, M.G.; Ditchfield, P.; Deviése, T.; Hedges, R.E.M.; et al. Metabolomics reveals diet-derived polyphenols accumulate in physiological bone. Sci. Rep. 2019, 9, 8047. [CrossRef] [PubMed]

25. Naumann, C.; Bassler, R. Die Chemische Untersuchung von Futtermitteln (Chemical Analyses of Animal Feed); VDLUFA-Verlag: Darmstadt, Germany, 2004.

26. Commission Directive 1999/79/EC of 27 July 1999 Amending the Third Commission Directive 72/199/EEC of 27 April 1972 Establishing Community Methods of Analysis for the Official Control of Feeding Stuffs. 1999. Available online: https://eur-lex.europa.eu/eli/dir/1999/79/oj (accessed on 26 June 2020).

27. Folin, O.; Ciocalteau, V. On tyrosine and tryptophane determination in proteins. J. Biol. Chem. 1927, 73, 424-427.

28. Waterman, P.G.; Mole, S. Analysis of Plant Metabolites. In Methods in Ecology Series; Waterman, P.G., Mole, S., Eds.; Blackwell Scientific Publications: Oxford, UK, 1994.

29. Pascual, J.J.; Castella, F.; Cervera, C.; Blas, E.; Fernandez-Carmona, J. The use of ultrasound measurement of perirenal fat thickness to estimate changes in body condition of young female rabbits. Anim. Sci. 2000, 70, 435-440. [CrossRef]

30. Oppenheim, F.G.; Offner, G.D.; Troxler, R.F. Aminoacid sequence of a proline-rich phosphoglycoprotein from parotid secretion of the subhuman primate Macaca fascicularis. J. Biol. Chem. 1985, 260, 10671-10679.

31. Ann, D.K.; Lin, H.H. Macaque salivary proline-rich protein: Structure, evolution, and expression. Crit. Rev. Oral Biol. Med. 1993, 4, 545-551. [CrossRef]

32. Marongiu, M.L.; Bovera, F.; Moniello, G.; Nizza, A.; Pinna, W. Influence of weaning age (28 vs. 63 d) on quantitative and qualitative carcass traits of rabbits. Ital. J. Anim. Sci. 2005, 4, 547-549. [CrossRef] 
33. Kadi, S.A.; Belaidi-Gater, N.; Chebat, F. Inclusion of crude olive cake in growing rabbits diet: Effect on growth and slaughter yield. In Proceedings of the 8th World Rabbit Congress, Puebla, Mexico, 7-10 September 2004; Volume 2, pp. 1202-1207.

34. Kadi, S.; Guermah, H.; Bannelier, C.; Berchiche, M.; Gidenne, T. Nutritive value of sun-dried Sulla (Hedysarum flexuosum) and its effect on performance and carcass characteristics of growing rabbits. World Rabbit Sci. 2011, 19, 151-159. [CrossRef]

35. Cappai, M.G.; Wolf, P.; Rust, P.; Pinna, W.; Kamphues, J. Raw hulled shredded acorns from Downy Oak (Quercus pubescens) in the diet of pigs: Effects on digestibility and faeces characteristics. J. Anim. Physiol. Anim. Nutr. 2013, 97, 1-5. [CrossRef]

36. Rodríguez-Estévez, V.; García, A.; Gómez-Castro, A.G. Intrinsic factors of acorns that influence the efficiency of their consumption by Iberian pigs. Livest. Sci. 2009, 122, 281-285. [CrossRef]

37. Galvan, J.V.; Valledor, L.; Ma, R.; Cerrilloc, N.; Pelegrind, E.G.; Jorrin-Novoa, J.V. Studies of variability in Holm oak (Quercus ilex subsp. Ballota) trough acorn protein profile analysis. J. Proteom. 2011, 74, 1244-1255. [CrossRef] [PubMed]

38. Nowar, M.S.; Al-Shawabkeh, K.; Nissour, H. Evaluation of Oak Acorn (Quercus coccifera) as Untraditional Energy Feedstuff for Complete Substitution of Corn Grains in Fattening Rabbit Ration. 1994. Available online: https://agris.fao.org/agris-search/search.do?recordID=QC9565291 (accessed on 26 June 2020).

39. Gasmi-Boubaker, A.; Abduli, H.; Lozada, M.M.; Tayachi, L.; Mansouri, M.; Zaidid, I. Cork oak (Quercus suber L.) acorn as a substitute for barley in the diet of rabbits; effect on in vivo digestibility, growth and carcass characteristics. J. Anim. Vet. Adv. 2007, 6, 1219-1222.

40. Nieto, R.; Rivera, M.; Garca, M.A.; Aguilera, J.F. Amino acid availability and energy value of acorn in the Iberian pig. Livest. Sci. 2002, 77, 227-239. [CrossRef]

41. Cappai, M.G.; Dimauro, C.; Biggio, G.P.; Cherchi, R.; Accioni, F.; Pudda, F.; Boatto, G.; Pinna, W. The metabolic profile of Asinara (albino) and Sardo donkeys (pigmented) (Equus asinus L., 1758) points to unequivocal breed assignment of individuals. PeerJ 2020, 8, e9297. [CrossRef]

42. Cappai, M.G.; Pudda, F.; Wolf, P.; Boatto, G.; Pinna, W. Variation of hematochemical profile and vitamin E status in feral Giara horses from free grazing in the wild to hay feeding during captivity. J. Equine Vet. Sci. 2020. [CrossRef]

43. St Claire, M.B.; Kennett, M.J.; Besch-Williford, C.L. Vitamin A toxicity and vitamin E deficiency in a rabbit colony. Contemp. Top. Lab. Anim. Sci. 2004, 43, 26-30.

(C) 2020 by the authors. Licensee MDPI, Basel, Switzerland. This article is an open access article distributed under the terms and conditions of the Creative Commons Attribution (CC BY) license (http://creativecommons.org/licenses/by/4.0/). 